\title{
SURVEY OF VIRAL DISEASES OF PACIFIC WHITE SHRIMP, Litopenaeus vannamei IN INDONESIA
}

\author{
Taukhid*), Hambali Supriyadi**), and Isti Koesharyani**)
}

\begin{abstract}
Penaeid shrimp culture is a major contributor to foreign exchange earning in Indonesia. It has significant impact on economic development of fisheries sector, and leads to be one of prime mover to improve social prosperity. However, shrimp industry particularly black tiger shrimp (Penaeus monodon) has been facing unpredictable situation due to disease problem. The main constrain in correlation to the development of shrimp industry is disease outbreak, especially caused by viral agents. White Spot Syndrome Virus (WSSV) occurred in 1994, causing mass mortality of black tiger shrimp almost in all of the middle and western part of Indonesia. Due to the disease problem, it is estimated that in year 2000 , more than $50 \%$ of shrimp pond were idle. Pacific white shrimp (Litopenaeus vannamei) or "udang vanamei" was introduced to Indonesia at the end of 1999, and released officially in July, 2001. Response of shrimp farmers to the shrimp rapidly accepted and distributed to many provinces in the country. At the end of 2006, distribution of white shrimp culture was encountered in more than 15 provinces. The seeds are mainly produced from hatcheries located in East Java and Lampung. The information of TSV in Indonesia was reported firstly from East Java at the end of 2002, without a clear history. Since then, survey of TSV distribution was conducted intensively in white shrimp production areas. Beside TSV, population of white shrimp coming to Indonesia also susceptible to White Spot Syndrome Virus (WSSV) and Infectious Hypodermal and Hematopoietic Necrosis Virus (IHHNV) infection. A survey with the aim to know significant viral diseases of white shrimp is needed to set up an alternative strategy to control them. The survey was conducted, firstly in the main production centers of white shrimp; and planned to be continued throughout the country. Samples collection, diagnostic method and data compiled in this study were collected from both active and passive surveillance. Diagnosis of viral diseases infecting white shrimp in this study was focused on TSV, WSSV, and IHHNV agents. Polymerase Chain Reaction (PCR) test has been used as a major diagnostic technique in this study. Progress report of the study showed that TSV spreading limited in controlled areas. The study proved that WSSV and IHHNV have been found in cultured white shrimp. All of the diseases mentioned above tend to be a significant constrain of future white shrimp industry in Indonesia, and special attention should be given in order to protect wide-spread of particular disease from infected to uninfected ones. Also, briefly current status of white shrimp culture development in the country will be discussed in this paper.
\end{abstract}

KEYWORDS: viral diseases, Pacific white shrimp, disease problem

") Research Institute for Freshwater Aquaculture, Bogor, Indonesia

**) Center Research Institute for Aquaculture, Jakarta, Indonesia 


\section{INTRODUCTION}

Penaeid shrimp culture is a major contributor to foreign exchange earning in Indonesia. It is has significant impact on economic development of fisheries sector, and leads to be one of prime mover to improve social prosperity. However, shrimp industry particularly black tiger shrimp (Penaeus monodon) has faced unpredictable situation due to complex problems. The main constrain in correlation to the development of shrimp industry is disease outbreak, especially caused by viral agents. White Spot Syndrome Virus (WSSV) occurred in 1994, causing mass mortality of black tiger shrimp almost in all of the middle and western part of Indonesia (Bali, Kalimantan, Sulawesi, Java, and Sumatra). Due to the disease problem, it was estimated that in year 2000 , more than $50 \%$ of shrimp pond were idle.

During a frustrating condition, there were several attempts by shrimp farmers to shift to other cultured species while others preferred to stop operation. Eventually, white shrimp, Litopenaeus vannamei or "udang vanamei" (in Indonesia) was chosen as an alternate species. The reasons of choosing white shrimp are: (i) it is relatively easier to culture, (ii) it performs better in terms of survival, and (iii) it requires less protein in its diet which means lower cost of shrimp production. Other claims the shrimp has better opportunity for export market, faster growth, and believed more resistant to particular disease.

The Government of Indonesia finally released a permit allowing white shrimp import on October 10, 2000 for research purpose only. The exotic shrimp was imported from Taiwan, Hawaii, and USA. And then, based on Ministerial Decree No. 4/2001 dated July 14, 2001 , the government allowed importation of white shrimp for culture purpose. In corresponding to implementation of the above permission, there are some following regulations and recommendations to protect sustainability of white shrimp industry in the country. One of the regulations is the only good quality and free TSV brood stocks are allowed to be imported to Indonesia. However, eventually revealed that soul of those shrimp were imported through an illegal importation from sources with unreliable health status.

L. vannamei has been cultured at least in more than 15 provinces in the country, and viral disease has been determined as one of significant constraint of white shrimp culture development. Beside TSV, populations of white shrimp coming to Indonesia are also susceptible to White Spot Syndrome Virus (WSSV) and Infectious Hypodermal and Hematopoietic Necrosis Virus (IHHNV) infection (Anonymous, 2004).

Disease surveillance is now becoming to be an integral component of all government aquatic animal health program. Surveillance is essential to ensure that activities are in place for early warning of diseases of concern, contingency planning and monitoring of disease control measures; provision of sound aquatic animal health advice to farmers, processors and other stakeholders involved in the handling of live aquatic animals; certification of exports; international reporting; and verification of freedom from diseases. Surveillance is particularly important for effective aquatic animal emergency disease preparedness.

Surveillance provides a mechanism for collecting and interpreting data on the health status of aquatic animal populations including specific diseases which are of concern to a country (Subasinghe et al., 2004). Diseases that warrant surveillance programs should be those that pose a significant threat to trade, productivity (wild or culture) and/or public health. These may be diseases listed as "notifiable" by the OIE (OIE, 2003), or any other diseases of special concern within a country (e.g. a National Pathogen List).

\section{OBJECTIVES}

The objectives of this study are to establish surveillance system of aquatic animal diseases, and to know the current status of significantly viral diseases infecting L. vannamei cultured in Indonesia by the end of 2006, especially caused by TSV, WSSV, and IHHNV. Information provided of the study would be useful to establish the following aspects:

- Provision of evidence of freedom from diseases relevant to domestic movement of the shrimp.

- Accurate description of the distribution and occurrence of diseases relevant to disease control and domestic movement of the shrimp.

- Assessment of control for selected diseases and pathogens, particularly to control program for TSV spreading around the country by zoning and limiting life shrimp 
transportation from an infected area to uninfected ones.

\section{MATERIALS DAN METHODS}

\section{Location}

The survey was conducted in 2006, firstly in the main production centers of white shrimp in the country. Five provinces were selected for the study, namely: East Java, Central Java, Yogyakarta, West Java, and Lampung. Sampling sites (spot area) were determined based on development and intensity of shrimp culture in all of provinces surveyed. Survey respondents were identified through stratified random sampling based on the latest official records. Randomly shrimp farmers were sampled at the each defined spot area.

\section{Sampling and Diagnostic Technique}

Shrimp samples were taken from both, hatchery and grow out pond by 3 spot areas of each province as a representing spot sampling location. Sample size of shrimp post larvae (PL) was 100-150 shrimps, and 30 shrimps for adult (grow out) or broodstock. PL obtained from the same population was pooled, and then preserved into alcohol $80 \%$ mixed with $20 \%$ glycerol in the same bottle. Adult shrimp or broodstock were preserved individually.

With the exception for adult shrimp or broodstock, prior detection for targeted viral agent was examined by pooled sample (10 specimens) per reaction. If the result was positive, further examination was taken individually. However, if the result was negative, no further examination was taken.

Diagnosis procedures to detect the present of viral agent infecting white shrimp was done by using TSV Primer-Kit Diagxotic ${ }^{\circledR}$, IQ2000 ${ }^{\text {TM }}$ Detection and Prevention System (Farming Intellegene Tech. Corp.), and Office Internationale des Epizooties (OIE) for Taura Syndrome Virus (TSV) infection; and by using IQ2000 TM Detection and Prevention System (Farming Intellegene Tech. Corp.) for both target agents, WSSV and IHHNV infection.

As a complementary of the study, semi structured questionnaires also were used to obtain information from the respondents in correlation with culture technique, recent problem encountered, and shrimp health management practiced.

\section{Data Analysis}

Samples collection, and data compiled in this study were collected from both, active and passive surveillance. Active surveillance is defined as the samples are taken and collected directly from the surveyed areas, and passive surveillance is defined as the samples were carried to the laboratory by either shrimp farmer or client. Viral diseases infecting white shrimp in Indonesia were listed in this report are compiled from two activities: (1) survey activity was conducted in 2003-2006, and (2) samples obtained from shrimp farmer or hatchery during these periods. Data obtained from both activities then analyzed descriptively. Geographical distribution of viral diseases infecting white shrimp were also refers to available information of 2006.

Information of present status, development, and impact of significant viral diseases of white shrimp culture in the country were analyzed descriptively, as well as shrimp health management technique practiced routinely, including general constrains have being faced by shrimp farmers. All of the beneficial information provided from the study would be used for further improvement.

\section{RESULTS}

\section{Status of White Shrimp Culture in Surveyed Area}

White shrimp culture in East Java and Lampung are completely developed, public interest highly appreciated as the shrimp are easily to culture and it is suitable to developed in Indonesia. In very short period, white shrimp culture covering all of the potential areas especially in both provinces, East Java and Lampung. Productivity levels of white shrimp culture in two pioneer provinces were mostly at the range of $10,000-15,000 \mathrm{~kg} / \mathrm{ha} / \mathrm{crop}$, and in some cases the production could up to 20,000-30,000 kg/ha/crop. However, as white shrimp price was relatively low (IDR $25,000-40,000 / \mathrm{kg}$ ); very high stocking density (>125 shrimps/m²).

Distribution of white shrimp in the country at the end of 2006 was at least in 15 provinces; namely: East Java, Central Java, West Java, Jogjakarta, Banten, Bali, West Nusa Tenggara, Lampung, South Sumatra, Riau, Bengkulu, West Sumatra, North Sumatra, South Sulawesi, South Kalimantan, East Kalimantan, and West Kalimantan (Figure 1). With the exception of 


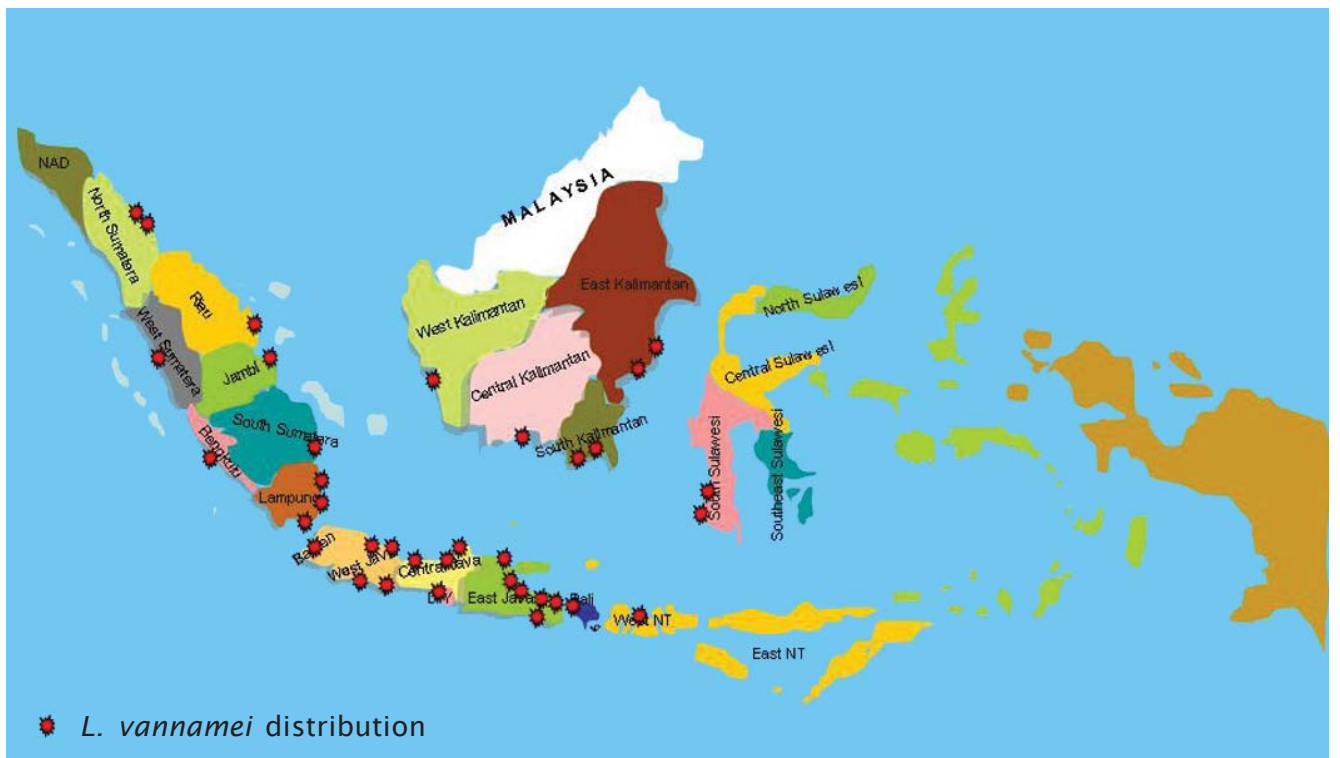

Figure 1. Distribution of Pacific white shrimp (L. vannamei) in Indonesia by the end of 2006

three provinces (East Java, Bali, and Lampung) development of white shrimp culture in other provinces were slower, even though there were many pioneer of shrimp farmers cultured the white shrimp. White shrimp culture in surveyed area: Jogjakarta, cultured in Kulon Progo district: in Central Java there were three districts, Brebes, Kendal, and Pati; and in West Java, cultured in Indramayu and Ciamis districts.

In the third year, there were many emerging constrains of white shrimp development in the country: (1) Report of harvest failures were more often caused by viral disease outbreak, (2) Due to sporadic spreading of white shrimp development in the country, it resulted to high demand of seeds, and consequently broodstocks. In certain area, shrimp farmers tried to producing their own spawners with unreliable broodstock management, and the product were sold to shrimp hatchery. Post larvae produced from local broodstock performed slower growth, broader size variation at harvest time, and to be more susceptible to disease.

Development of white shrimp culture in Indonesia is getting better and wide-spread throughout the country. Fast growing of white shrimp development followed by highly requesting seed supply. In reality, broodstock of white shrimp is commercially available, and easy for shrimp hatchery to order the mother shrimps. The species is fully domesticated so that Specific Pathogen Free (SPF) broodstock is now readily available. This is actually competitive with the price of wild-caught natural black tiger shrimp spawners, which is getting scarcer and more expensive aside from the fact that many wild stocks have been already infected by viral agents.

Recently, most of black tiger shrimp farmers used to apply traditional or conventional culture system are waiting for further news of white shrimp development, especially in terms of stable price on booming product time, government supports and recommendation of culture technique in order to operate idle ponds within available condition and capital limit.

\section{Geographical distribution of significant viral diseases of white shrimp in Indonesia}

Geographical distribution of targeted agents revealed that TS virus has been detected in East Java, West Java, Bali, and West Nusa Tenggara. Further, there was a report of disease outbreak on white shrimp culture in Brebes (Central Java) and South Sulawesi, however, we have no original sample to proof of confirmative diagnosis. Those reports would be valuable information for next targeted spot 
areas in this study. Interestingly, Lampung province one of pioneers of white shrimp development in the country, at the end of 2006 there was no report or laboratories data of TS infection, meaning that Lampung remained TSVfree area.

WSSV and IHHNV infection on white shrimp culture have been detected in all of surveyed areas (East Java, Bali, Central Java, West Java, and Lampung), and also sample from West Nusa Tenggara. Both of viral agents, WSSV and IHHNV were believed as endemic disease of penaeid shrimp in Indonesia. It seemed that although there be some needs to establish disease free in each province, it appear no practical approach. This is because of the husbandry methods practiced and a perception by shrimp farmers that both of the diseases are cosmopolitan and diseases occur only when there is a problem in seed screening and pond management. Summary of geographical distribution of significant viral diseases of white shrimp culture in Indonesia at the end of 2006 could be seen in Figure 2.

Data compiled in this study were collected from both, active and passive surveillance. Viral diseases infecting white shrimp in Indonesia listed in this report are compiled from two activities: (1) survey activity conducted in 2003-2006, and (2) samples obtained from shrimp farmer or hatchery during this period. Geographical distribution of viral diseases in- fecting white shrimp were also refered to available information as of 2006.

Total of collected sample in the study was 317 pcs. From those, as many as 272 samples have been analysed for TSV detection, 221 for WSSV, and 182 for IHHNV. Summary of the collected samples and analyses in this study are shown in Table 1, and prevalence of viral agents obtained in each provinces are provided in Table 2. The highest TSV prevalence was found in East Java (41.18\%), followed by West Nusa Tenggara (31.43\%), Bali (25.00\%), and West Java (20.00\%).

Based on available data, it seems that cultured white shrimp in the country has been infected by WSSV in all of surveyed areas. The highest prevalence of WSSV was found in West Java (50.00\%), followed by Bali (33.33\%), Lampung (15.89\%), West Nusa Tenggara (1 1.76\%), Central Java (8.33\%), and Jogjakarta (7.14\%). The IHHNV infecting the white shrimp was also obtained in all of surveyed areas, the highest prevalence of IHHNV was found in Bali, followed by East Java, Central Java, Lampung, West Java, and West Nusa Tenggara.

Results of PCR detection showed that all of concerned agents have been detected on white shrimp cultured in certain areas, founded either in PL or adult stage. TSV and WSSV infection were mostly detected from adult shrimp, although there was a case that WSSV infection was obtained from PL stage. Generally, IHHNV

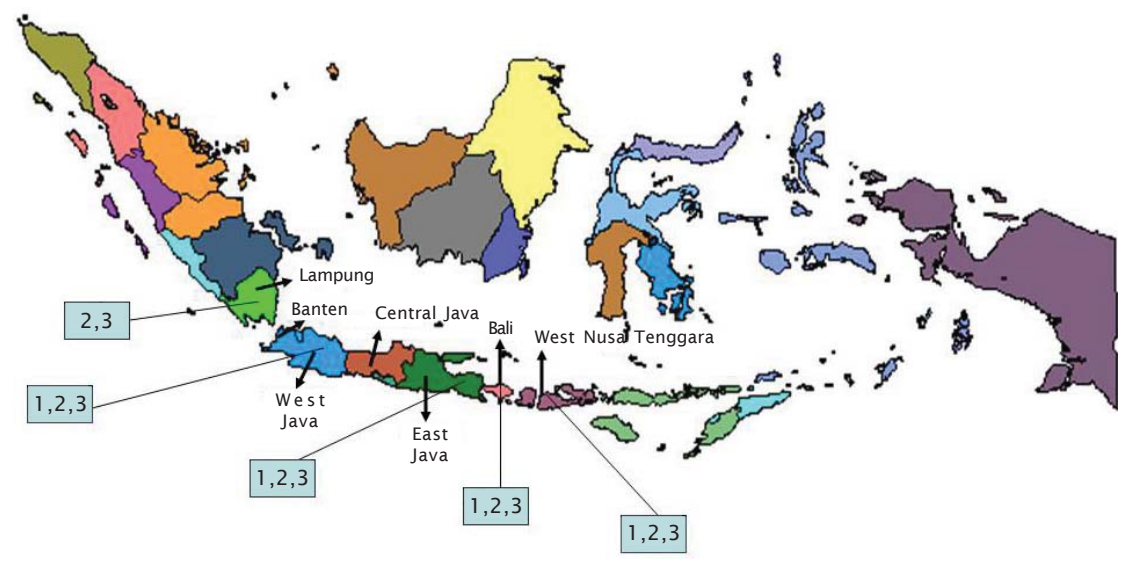

1 = Taura Syndrome Virus

$2=$ White Spot Syndrome Virus

$3=$ Infectious Hypodermal and hematopoletic Necrosis Virus

Figure 2. Geographical distribution of significant viral diseases of white shrimp culture (L. vannamei) in Indonesia at the end of 2006 
Table 1. Total of white shrimp samples and total of samples analysed for each viral agents

\begin{tabular}{|c|c|c|c|c|}
\hline Provinces & $\Sigma$ sample & TSV & WSSV & IHHNV \\
\hline Lampung & 147 & 126 & 107 & 87 \\
\hline West Java & 12 & 10 & 12 & 10 \\
\hline Central Java & 12 & 10 & 12 & 10 \\
\hline East Java & 81 & 68 & 44 & 29 \\
\hline Bali & 4 & 1 & 3 & 2 \\
\hline Yogyakarta & 14 & 10 & 14 & 10 \\
\hline Banten & 12 & 12 & 12 & 12 \\
\hline West Nusa Tenggara & 35 & 35 & 17 & 22 \\
\hline Total & 317 & 272 & 221 & 182 \\
\hline
\end{tabular}

Table 2. Prevalence (\%) of concerned viral agents in surveyed areas

\begin{tabular}{lccc}
\hline \multicolumn{1}{c}{ Provinces } & $\begin{array}{c}\text { TSV } \\
\text { prevalence }\end{array}$ & $\begin{array}{c}\text { WSSV } \\
\text { prevalence }\end{array}$ & $\begin{array}{c}\text { IHHNV } \\
\text { prevalence }\end{array}$ \\
\hline Lampung & 0.00 & 15.89 & 18.39 \\
West Java & 20.00 & 50.00 & 10.00 \\
Central Java & 0.00 & 8.33 & 20.00 \\
East Java & 41.18 & 11.36 & 27.59 \\
Bali & 25.00 & 33.33 & 50.00 \\
Yogyakarta & 0.00 & 7.14 & 0.00 \\
Banten & 0.00 & 0.00 & 0.00 \\
West Nusa Tenggara & 31.43 & 11.76 & 4.55 \\
\hline
\end{tabular}

infection was detected in both stages PL and adult stage. Representing figures of PCR detection are given in Figure 3-5. The compiled data sheet of samples, origin of the samples and detection technique used in the study provided are in the appendix.

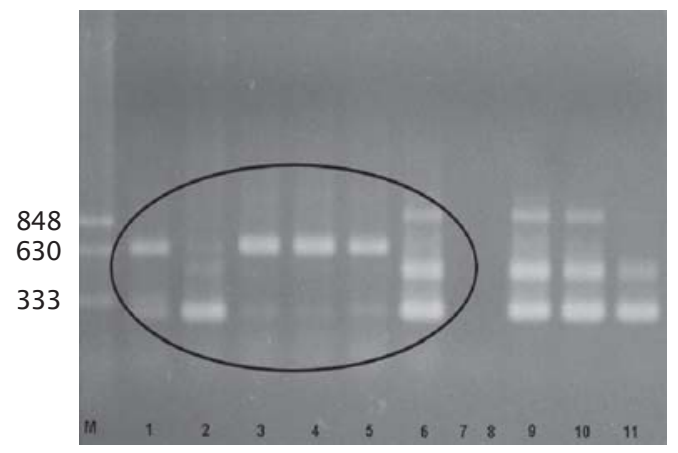

\section{DISCUSSIONS}

One of the purposes of introducing pacific white shrimp is to improve national shrimp production, as the shrimp was believed has larger opportunity for export market. At the

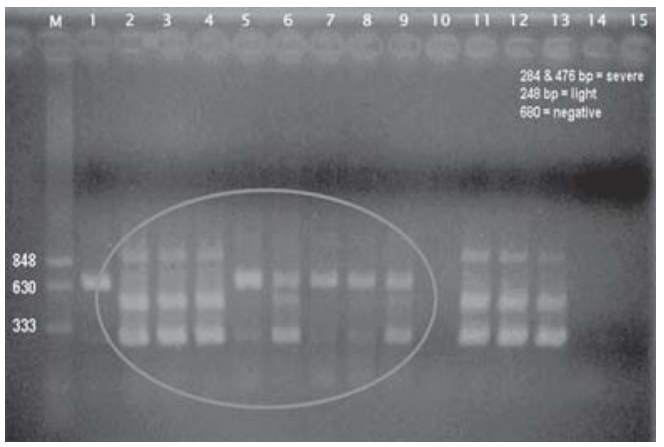

Figure 3. Profile of polymerase chain reaction (PCR) test of white shrimp samples infected by Taura Syndrome Virus 


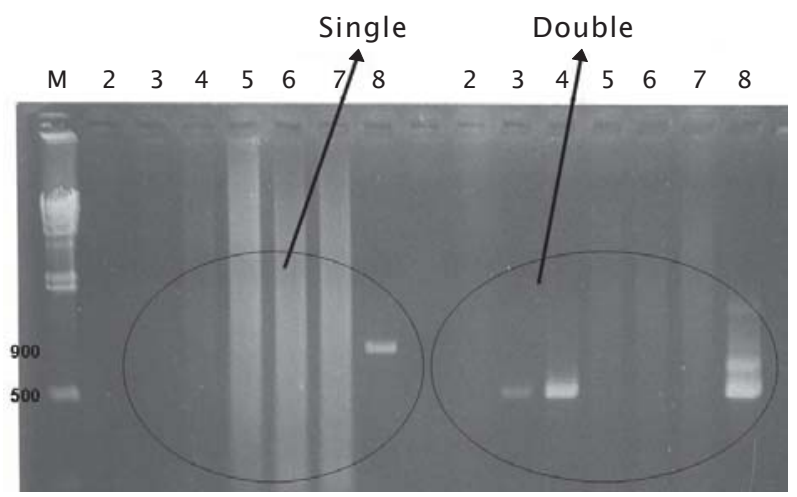

Figure 4. Profile of polymerase chain reaction (PCR) test of white shrimp samples infected by White Spot Syndromes

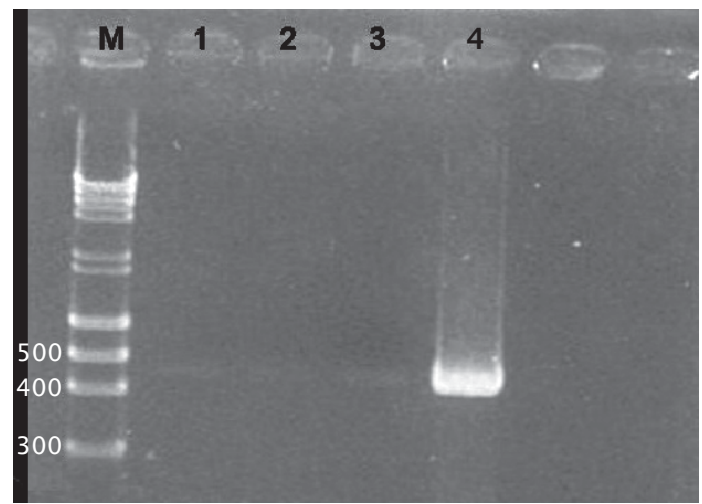

Figure 5. Profile of polymerase chain reaction (PCR) test of white shrimp samples infected by Infectious Hypodermal and Hematopoietic Necrosis Virus

beginning, there were some advantages of white shrimp compared to black tiger shrimp: (1) faster growth especially in the first 60 days post cul-ture, (shorter period to gain commercial size) (size $60-80 \mathrm{p} / \mathrm{kg}) ;(2)$ homogenous size at harvest time; (3) feed price of white shrimp is cheaper with lower feed conversion ratio (FCR); (4) more resistant to particular disease and environmental changes, (5) higher productivity as white shrimp are active swimmer, and (6) culture technique both shrimp species is similar.

Success story of white shrimp culture, especially in East Java, Lampung and Bali has encouraged other shrimp farmers in neighboring provinces, to culture the shrimp. Besides as pioneer of white shrimp culture, East Java and Lampung were also a source for the seeds. Many of black tiger shrimp hatchery switched to become white shrimp seed producer, and the seeds were distributed to neighboring provinces. Surprisingly, most of shrimp farmers in Lampung provinces, only use white shrimp produced from imported broodstock (Taukhid et al., 2004). It was the fact that imported broodstock produced better performance in growth and to guarantee TSV free.

Within 2-3 years, white shrimp production seemed to overtake the black tiger shrimp. Intensification or even conventional culture system of black tiger shrimp culture slowed down in favor of the white shrimp. Budhiman et al. (2005) reported that production of white shrimp has increased significantly from $29.3 \%$ in 2002 to $47.6 \%$ in 2004 , and could be $66.7 \%$ in 2005 or about two-thirds of the national aquaculture shrimp production.

Since the black tiger shrimp is one of promising export commodity, with lower competi- 
tive and better price in the global market compared to white shrimp, most of traditional shrimp farmers in the country remained culturing the shrimp even with very low stocking density $\left(1-2\right.$ shrimps $\left./ \mathrm{m}^{2}\right)$. Even though the white shrimp lead already in national shrimp production, however, the government and shrimp farmers were highly concerned in correlation to developing the native species, black tiger shrimp. It is believed that the species remains promising for future development.

There were 419,282 hectares of brackish water ponds and potential area of 913,000 hectares in Indonesia. Department of Fisheries and Marine Affair has made short, middle and long term strategies toward development of shrimp industry in the country, and it was a big chance of Indonesia to become one of the big shrimp producers and exporters in the world (Budhiman et al., 2005). Developing the new culture species has proved to enhance the shrimp industry, and increased national shrimp production accordingly. National shrimp culture production in 2004 was approximately 250,000 metric tons and significantly increased to 300,000 tons in 2005. During 2004-2005, white shrimp production accounted for approximately $50 \%-65 \%$ of the cultured shrimp production. At the moment, national white shrimp culture production was mainly provided by the industries applying intensive culture system, and total of such shrimp ponds in the country was only $15 \%$ $25 \%$ of 419,282 hectares, and it was expected that white shrimp production contribute as much as two-thirds of the national aquaculture shrimp production in 2006 . The remaining shrimp ponds $(75 \%-85 \%)$ mostly applied conventional or semi-intensive culture system. It would be multiplied dramatically if the revitalizing program of idle ponds, canal realignment and zoning improvement were realized for white shrimp culture purpose.

Unfortunately, the tendency to apply high stocking density in several production centers, the farmers would be able to gain higher yield, but it is harmful due to internal pollution in rearing ponds, along of drain canal, and some extent also to incoming water source. This situation of course result in environmental deterioration in relatively short period due to internal pollution. Without any program of environmental management concern and integrative proper implementation, the future of white shrimp industry would be blackened in several coming years.
Increased awareness of negative impact of diseases in shrimp culture has evolved impressively and rapid growth of penaeid shrimp aquaculture was observed in the country. An increase in reports of disease with infectious and non-infectious etiologies has also occurred. During recent years various diseases affecting shrimp production have been reported in Indonesia. The most important disease lasting until present has been WSSV, which has affected cultured black tiger shrimp in major production centers of penaeid shrimp in the country. Unfortunately, in the beginning of 2003 using polymerase chain reaction (PCR) test, TSV was also detected in white shrimp cultured in East Java, and it seemed subsequently to start spreading to uninfected areas.

It is a natural phenomenon that intensification of specific organisms is often to be followed by disease problem, and it is no exception for shrimp industry in Indonesia. At the beginning of white shrimp culture in Banyuwangi and Situbondo districts (East Java) there were proved that the shrimp could be cultured successfully without any disease problem, even though the other species, black tiger shrimp culture were being infected by WSSV leading to failure harvest located by near the white shrimp ponds. Taukhid et al. (2003) stated that if there were no serious attentions to be given in disease control program, success story of white shrimp culture would be inhibited by disease problem started at the beginning of 2003 when a serious disease outbreak occurred in main part of shrimp pond along of northern part of East Java coastline. The causative agent of the disease confirmed as TSV infection, and it was the first episode of TSV outbreak in Indonesia.

Since disease outbreak occurred on white shrimp culture, shrimp industry started to realize the need to improve awareness for further unpredictable situation in term of disease control. Even though, disease outbreak caused by TSV infection did not cause total mortality, however, it was the fact that the population of white shrimp introduced to Indonesia not only susceptible to TSV infection, but also susceptible to WSSV and IHHNV infection (Anonymous, 2004). Both of viral agents, WSSV and IHHNV were believed as endemic disease of penaeid shrimp in Indonesia. It has often been reported that disease outbreak on white shrimp culture was caused by not only single agent, but may be double or even triple agents of viral infection. 
TS virus generally infect juvenile white shrimp $(0.1-5.0 \mathrm{~g})$ within two to six weeks after stocking in grow out ponds, but in some cases they also infect adult shrimp (75 days after stocking). TSV is primarily an illness of the cuticle epidermis (outer exoskeleton) in shrimp. Shrimp in the chronic phase of TSV have scattered, black-spot lesions along their outer skin or shell. During TSV outbreaks, dead and dying shrimp will often be seen in seines or cast nets used for routine population sampling or found lying along the bottom of the grow-out ponds. Shrimp afflicted with the acute phase of TSV appear weak and disoriented, have soft-shells, and have expanded chromataphores (pigment spots) that may alter their color slightly. Infected shrimp also have empty digestive tracts.

White spot syndrome (WSS) is a shrimp viral disease resulting in a serious economic impact on cultured black tiger shrimp in Indonesia. Penaeid shrimp aquaculture production grew rapidly in the 1980 s. In 1985 , national production of farmed shrimp was 180,000 metric tons and drastically decreased to 135,058 metric tons in 1994; and in 1997 it reached 167,445 metric tons (Taukhid et. al., 2003). But since then, largely due to the outbreak of WSSV, national shrimp aquaculture production has stagnated and, it has even gone down over the last few years. National shrimp aquaculture production has started to grow up dramatically since 2003, after the new comer repositioning the native species.

WSS disease outbreak on white shrimp culture in the country firstly reported in the middle of 2003s in Situbondo district. Afterward, many outbreaks occurred in different places (Brebes, Banyuwangi, Bangil, and Sidoarjo) in the same year. Based on PCR detection system, it has been confirmed that the causative agent is WSSV infection. In the following year (2004 and 2005), WSS outbreak on white shrimp culture was reported coming from West Java and Lampung provinces. Again, confirmation by PCR test was proved that the causing agent was WSSV infection. Mortality rate of white shrimp infected by WSSV were often higher than that of by TSV. As a comparison, we had no information of mortality rate due to TSV infection on white shrimp higher than $70 \%$; mostly at the range of $20 \%-60 \%$; however, WSSV infection mostly caused harvest failure or of more than $90 \%$ mortality rate. At the moment, white shrimp farmers more likely prefer to check the seed are WSSV-free instead of TSVfree prior stocking.

The most surprising feature of WSSV is its wide range of potential hosts. It infects not only the penaeid shrimps but also a wide range of other decapods including crab, crayfish, and lobster. PCR has also detects the virus in artemia, copepod and insect larvae, but it has not yet been established whether these arthropods are susceptible to actual WSSV infection. The virus can be transmitted horizontally either orally by predation on diseased individuals, or by virus particles in the water, presumably through the gills (Chou et al., 1995; 1998). Potential routes for introduction of shrimp viral diseases to aquaculture facilities include infected broodstock, contaminated vehicles, containers, and other fomites, and transfer by birds and bird feces.

In white shrimp, IHHNV infection can cause Runt Deformity Syndrome (RDS), an illness that often has a significant impact on a farm's productivity by reducing a shrimp's potential for growth. While healthy shrimp crops generally grow at uniform rates (simplifying harvesting, sorting, and marketing), IHHNV infected shrimp crops typically have a large disparity in growth rates. Crop losses from poor feed conversion, reductions in weight and increased sorting costs need to be closely managed by a shrimp farmer in order to turn a profit.

There is no available accurate data of economic losses due to disease outbreak on white shrimp industry in the country. However, there were many reports that due to the disease they lost profit or in some extent to stop operation. Concerns were voiced of the need for support by the government of disease control programs and the need to address this issue, including restrictions on movement of live shrimp from infected zone to uninfected ones.

\section{CONCLUSIONS}

- Pacific white shrimp (L. vannamel) or "udang vanamei" has significant impact on national shrimp aquaculture production in Indonesia. Production of white shrimp has increased significantly from $29.3 \%$ in 2002 to $47.6 \%$ in 2004 , and could be two-thirds of the national aquaculture shrimp production in 2006.

- Distribution of white shrimp at the end of 2006 have been cultured in 15 provinces; namely: East Java, Central Java, West Java, 
Jogjakarta, Banten, Bali, West Nusa Tenggara, Lampung, South Sumatra, Riau, Bengkulu, West Sumatra, North Sumatra, South Sulawesi, South Kalimantan, East Kalimantan, and West Kalimantan.

- Disease problem is more likely a significant constraint in the development of white shrimp industry. Taura Syndrome Virus (TSV) was firstly detected in East Java, and it subsequently started spreading to uninfected areas. The population of white shrimp imported to Indonesia was also susceptible to White Spot Syndrome Virus (WSSV) and Infectious Hypodermal and Hematopoietic Necrosis Virus (IHHNV) infection.

- Geographical distribution of TSV has been detected in East Java, West Java, Bali and West Nusa Tenggara. Meanwhile, WSSV and IHHNV infecting white shrimp culture have been detected in all of the surveyed areas (East Java, Bali, Central Java, West Java, and Lampung), and also samples from Banten and West Nusa Tenggara.

\section{ACKNOWLEDGEMENTS}

This study was supported by the Regional Fish Disease Project Funded by the Government of Japan Trust Fund, through the Aquaculture Department-Southeast Asian Fisheries Development Center.

\section{REFERENCES}

Anonymous. 2004. Viral diseases infecting Litopenaeus vannamei cultured in Indonesia. Collection sheet of diagnostic report of Fish Health Research Laboratory, Jakarta. (unpublished data).
Budhiman, A.A., T.S. Paryanti, and A. Sunaryanto. 2005. The present status of Penaeus vannamei and other exotic shrimp culture in Indonesia. Proceeding of Regional Technical Consultation on the Aquaculture of Penaeus vannamei and other exotic shrimps in Southeast Asia. Manila, Philippines 1-2 March 2005. Aquaculture Department, Southeast Asian Fisheries Development Center, Tigbauan, Iloilo, Philippines. p. 42-49.

Chou, H.Y., C.Y. Huang, C.H. Wang, H.C. Chiang, and C.F. Lo. 1995. Pathogenicity of a baculovirus infection causing white spot syndrome in cultured penaeid shrimp in Taiwan. Diseases of Aquatic Organisms. 23: 165-173.

Chou, H.Y., C.Y. Huang, C.F. Lo, and G.H. Kou. 1998. Studies on the transmission of white spot syndrome associated baculovirus (WSBV) in Penaeus monodon and $P$. japonicus via waterborne contact and oral ingestion. Aquaculture. 164: 263-276.

OIE. 2003. Manual of Diagnostic tests for Aquatic Animals. 2003. (Fourth Edition), 358 pp OIE, Paris. http://www.oie.int/eng/normes/ fmanual/A_summry.htm

Subasinghe, R.P., S.E. McGladdery, and B.J. Hill. 2004. Surveillance and zoning for aquatic animal diseases. FAO Fisheries Technical Paper 451. Rome, Italy.

Taukhid, A. Sunarto, I. Koesharyani, H. Supriyadi, L. Gardenia, S. Partasasmita, and P. Taufik. 2003. Monitoring of potential diseases of Litopenaeus vannamei in Java. Technical Report of Research Centre for Aquaculture. 